
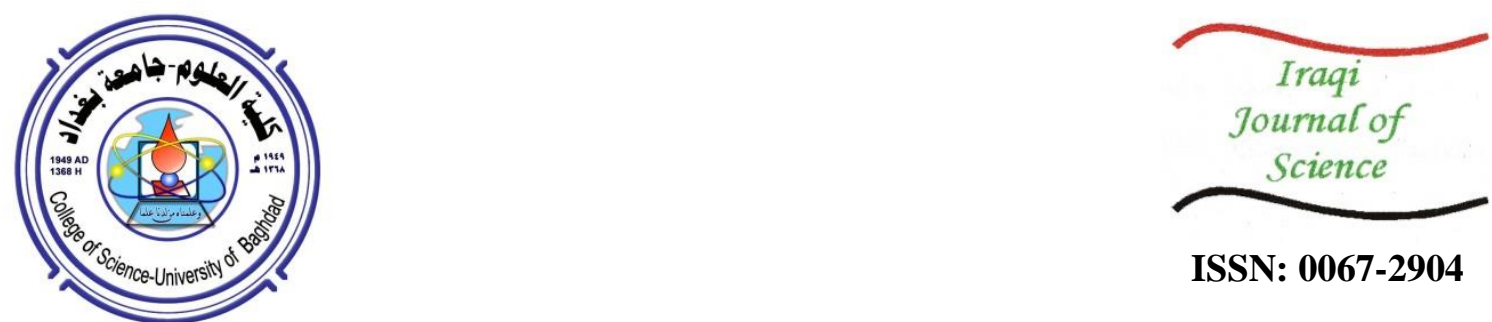

ISSN: 0067-2904

\title{
Synthesis and Identification of Some New Derivatives of ([Benzyl Thio) Benzimidazole -N- (Methylene-5-Yl)] - 4,5- Di Substituted 1,2,4-Triazole and Evaluation of Their Activity as Antimicrobial and Anti-Inflammatory Agents
}

\author{
Suaad, M. H. Al-Majidi, Halah, A.R. Ibrahim \& Yasser, A.H. AL-issa \\ Department of chemistry, College of Science, University of Baghdad, Baghdad, Iraq
}

Received: $13 / 1 / 2020$

Accepted: 29/9/2020

\begin{abstract}
:
New 2-Mercaptobenzimidazole derivatives were synthesized. 4,5-disubsitituted 1,2,4-Triazole compounds $\mathbf{1 b}-\mathbf{2 c}$ were synthesized from 2-(benzylthio) benzimidazole compound a, which was then reacted with $(\mathrm{NaH})$ in dioxane at a temperature of $\left(0-5 \mathrm{C}^{\circ}\right)$ to produce the salt of compound $\mathbf{a}$. Then the salt was reacted with ethyl chloro acetate to yield Ethyl 2-(benzylthio) benzimidazole acetate compound $\mathbf{b}$. Compound $\mathbf{b}$ was converted to triazole derivatives by two pathways. The first pathway was reacting compound $\mathbf{b}$ with semicarbazide, thiosemicarbazide and phenylsemicarbazide in DMSO as a solvent to gain compounds $\mathbf{1 b}-\mathbf{3 b}$, which were then cyclized by refluxed with $2 \mathrm{~N}(\mathrm{NaOH})$ to yield 1,2,4-triazole derivatives

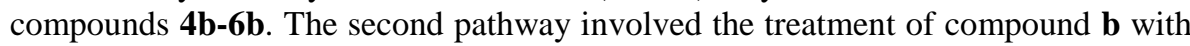
hydrazine hydrate to produce N-acetohydrazide-2-(benzyl thio) benzimidazole c. Compound $\mathbf{c}$ was refluxed with carbon disulfide $\left(\mathrm{CS}_{2}\right)$ in $\mathrm{KOH}$ alcoholic solution to obtain the salt compound 1c. The salt was treated with hydrazine hydrate to yield 1,2,4-triazole derivative compound 2c. The newly synthesized compounds b-2c were identified by FTIR, ${ }^{1} \mathrm{H}$-NMR and ${ }^{13} \mathrm{C}$-NMR and their physical properties were measured. Furthermore, their anti-microbial activities were tested against two Grampositive and two Gram-negative bacteria and against one strain of fungi. Also, some of these synthesized compounds were tested for their anti-inflammatory activities.
\end{abstract}

Keywords: 2-Mercaptobenzimidazole, semicarbazide, thiosemicarbazide, phenylsemicarbazide 1,2,4-triazole, Anti-Microbial, Anti-inflammatory.

\section{تحضير وتثخيص بعض المشتقات الجديدة من 2- [ بنزيل ثايو بنزإيميدازول-N-

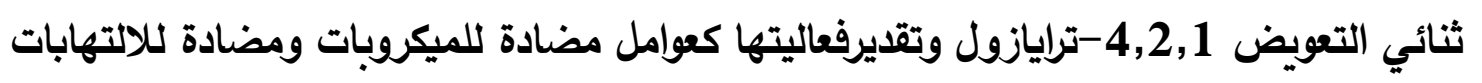

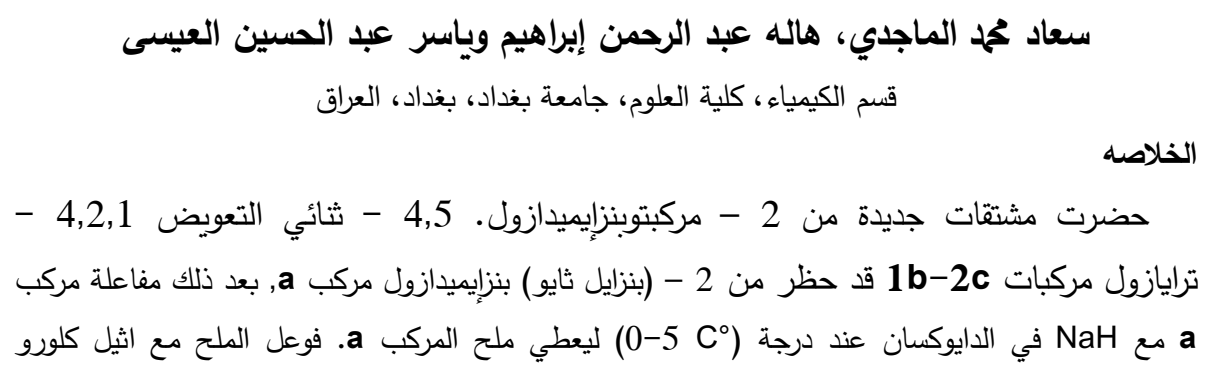




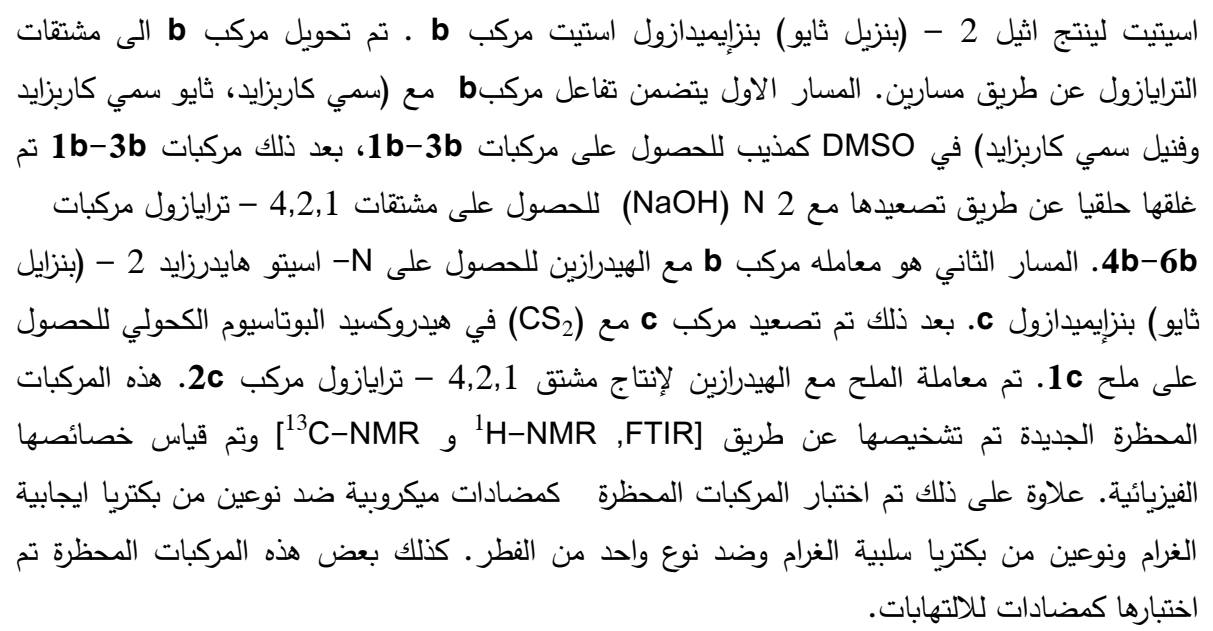

\section{Introduction}

Inflammation is one of the initial signs of many well-known diseases and described by symptoms including swelling, heat, redness, and pain. In recent times, a small number of benzimidazoles were discovered to have anti-inflammatory and antibacterial activities [1]. Benzimidazole is one of the most exceptional hetero cyclic moieties that produced many effective drugs. A wide range of pharmacological activities were informed by benzimidazole moiety itself and its derivatives [2]. The benzimidazole structure is related with a wide range of biological activities including anti-cancer [3], anti-viral [4], anti-inflammatory [5], anti-oxidant [6] and antimicrobial [7] properties. A countless number of five-membered heterocyclic compounds that contain nitrogen, sulfur and oxygen were synthesized and their numerous pharmacological properties were studied. Of these compounds, 1,2,4triazoles are known to be used to improve the pharmacokinetic properties (excretion, metabolism, distribution and absorption) of drugs [8]. Furthermore, 1,2,4-triazole derivatives have significant pharmacological properties [9], for example analgesic [10], antifungal [11], antibacterial [12, 13], anticonvulsant [14], anti-inflammatory [15], antiviral [16], antimalarial [17] and antioxidant [18].

\section{Experimental Work}

All chemicals used in this work were supplied by Merck, Fluka, BDH and sigma Aldrich chemicals companies. The FTIR spectra were recorded using FTIR 8400s Fourier transitions infrared spectrometer (Shimadzu, Japan), $\mathrm{KBr}$ disc in $4000-600 \mathrm{~cm}^{-1}$ spectral range, in the Department of Chemistry, College of Science, University of Baghdad. The melting point was recorded using Gallenkamp, electro-thermal apparatus. ${ }^{1} \mathrm{H}-\mathrm{NMR}$ and ${ }^{13} \mathrm{C}-\mathrm{NMR}$ spectra were recorded on near magnetic resonance Bruker, Ultra-shield (400) MHz. Also, DMSO- $\mathrm{d}_{6}$ was used as a solvent in the experiment conducted in Isfahan University, Iran. The antimicrobial activity was tested at the Central Service laboratory, College of Education for pure Science (Ibn Al-Haitham), University of Baghdad. The anti-inflammatory activity was detected at the Drug Control Center / Iraqi Ministry of Health.

\section{Synthesis of 2-(benzyl thio) benzimidazole a [19]}

The compound 2-marcaptobenzimidazole [2-MBI] (1.5 g, 0.0099 mol.) was dissolved in $(5 \mathrm{~mL})$ of absolute ethanol and stirred for about $(5 \mathrm{~min})$. Then, $\mathrm{KOH}$ alcoholic solution was prepared from $(0.560 \mathrm{~g}, 0.0099 \mathrm{~mol}$.) $\mathrm{KOH}$ with $3 \mathrm{~mL}$ absolute ethanol and added slowly to the solution of [2-MBI], followed by stirring for $(10 \mathrm{~min})$. Then, $(1.13 \mathrm{~mL}, 0.0099 \mathrm{~mol}$.) benzyl chloride was added to the solution and left to reflux for $(4 \mathrm{~h})$. The reaction mixture was poured on ice water with stirring, filtered to produce a white precipitate and, re-crystallized from ethanol and water (1:1). The physical properties and FTIR spectral data are listed in Table-1.

Synthesis of N-ethyl -2-(benzylthio) benzimidazole acetate $\mathbf{b}$ [20].

The compound 2-benzyl thiobenzimidazole a $(0.005$ mol., $1.2 \mathrm{~g})$ was mixed with $5 \mathrm{~mL}$ dioxane in a round bottom flask and stirred for $(5 \mathrm{~min})$. While the precipitate was dissolved and the solution became clear, the round bottom flask was put in ice water bath and $\mathrm{NaH} 0.2 \mathrm{~g} 0.005 \mathrm{~mol}$.) was added slowly, followed by stirring for about $30 \mathrm{~min}$ at $0 \mathrm{mC}^{0}$. After that, ethyl chloro acetate $(0.6 \mathrm{~mL}, 0.005$ mol.) was added drop by drop and stirred in room-temperature overnight. The solution was poured on 
iced water and filtered to give an off-white precipitate. The physical properties and FTIR spectral data are listed in Table-1.

Synthesis of 2-[(benzyl thio)benzimidazole -N- (Aceto)] semicarbazide $1 \mathrm{~b}$, thiosemicarbazide $2 \mathrm{~b}$, and phenylsemicarbazide $3 \mathbf{b}[21]$

Compound b $(0.5 \mathrm{~g}, 0.0015 \mathrm{~mol})$ was dissolved in $(5 \mathrm{~mL})$ (DMSO), then $(0.0015 \mathrm{~mol}$.) of semicarbazide, thiosemicarbazide, and phenylsemicarbazide were added respectively and stirred for some minutes. Then, sodium acetate $(0.123 \mathrm{~g}, 0.0015 \mathrm{~mol})$ was added to the reaction mixture and refluxed for (18-20 h). Finally, the reaction mixture was poured on ice-cold water. The precipitate was filtered and recrystallized from ethanol to give crystals. Physical properties and FTIR spectral data for compounds $\mathbf{1 b - 3 b}$ are listed in Table-1.

Table 1-Physical properties and FTIR spectral data for compounds $\mathbf{a - 3 b}$

\begin{tabular}{|c|c|c|c|c|c|c|c|c|c|}
\hline \multirow[b]{2}{*}{$\begin{array}{c}\text { No } \\
\cdot\end{array}$} & \multirow[b]{2}{*}{$\begin{array}{c}\text { Compound } \\
\text { Structure }\end{array}$} & \multicolumn{3}{|c|}{ Physical Properties } & \multicolumn{5}{|c|}{ FTIR absorption $\mathbf{c m}^{-1}$} \\
\hline & & $\begin{array}{c}\text { M.P } \\
\text { C }^{0}\end{array}$ & $\begin{array}{l}\text { Yiel } \\
\text { d \% }\end{array}$ & Color & $\mathbf{v}\left(\mathrm{N}-\mathrm{H}_{2}\right)$ & $\begin{array}{l}\mathbf{v}(\mathrm{N}- \\
\mathrm{H})\end{array}$ & $\begin{array}{c}\mathbf{v}(\mathrm{C}- \\
\text { H) } \\
\text { Arom }\end{array}$ & $\mathbf{v}(\mathrm{C}=\mathbf{O})$ & $v(C=N)$ \\
\hline $\mathbf{a}$ & & $\begin{array}{c}186- \\
188\end{array}$ & 94 & White & - & 3134 & 3049 & - & 1628 \\
\hline b & & $\begin{array}{c}54- \\
56\end{array}$ & 82 & $\begin{array}{c}\text { Off } \\
\text { white }\end{array}$ & - & - & 3055 & $\begin{array}{c}\text { Ester } \\
1753\end{array}$ & 1641 \\
\hline $1 b$ & & $\begin{array}{l}158- \\
160\end{array}$ & 63 & $\begin{array}{c}\text { Off } \\
\text { white }\end{array}$ & $\begin{array}{c}\text { Asym. } \\
3438 \\
\text { Sym. } \\
3398\end{array}$ & 3245 & 3066 & $\begin{array}{c}\text { amid } \\
1695\end{array}$ & 1650 \\
\hline $\mathbf{2 b}$ & & $\begin{array}{l}168- \\
170\end{array}$ & 75 & $\begin{array}{c}\text { Off } \\
\text { white }\end{array}$ & $\begin{array}{c}\text { Asym. } \\
3468 \\
\text { Sym. } \\
3417\end{array}$ & 3232 & 3066 & $\begin{array}{c}\text { amid } \\
\text { overlap } \\
\text { with } \\
v(\mathrm{C}=\mathrm{N})\end{array}$ & 1620 \\
\hline $\mathbf{3 b}$ & & $\begin{array}{c}166- \\
168\end{array}$ & 64 & brown & $\longrightarrow$ & 3255 & 3066 & $\begin{array}{c}\text { amid } \\
1664\end{array}$ & 1620 \\
\hline
\end{tabular}

Synthesis of 2-[ (benzyl thio) benzimidazole -N- (methylene-5-yl)]-4H-1,2,4-triazole-3-ol $4 \mathrm{~b}, 4 \mathrm{H}$ 1,2,4-triazole-3-thiol 5b, and 4-phenyl-1,2,4-triazole-3-ol 6b [8]

Compounds $\mathbf{1 b}-\mathbf{3 b}(0.001 \mathrm{~mol}$.) were refluxed with $2 \mathrm{~N}$ sodium hydroxide solution $(25 \mathrm{~mL})$ for $10-12$ h. The reaction mixture was cooled to room temperature, poured on ice-cooled water, stirred, and neutralized by gradual addition of $(1: 1)$ hydrochloric acid. The formed precipitate was filtered and recrystallized from ethanol. Physical properties and FTIR spectral data for compounds $\mathbf{4 b} \mathbf{b}-\mathbf{6 b}$ are listed in Table-2.

Synthesis of N- acetohydrazide -2-(benzylthio) benzimidazole c [20]

Compound $\mathbf{b}(0.5 \mathrm{~g}, 0.0015 \mathrm{~mol}$.) was dissolved with $(5 \mathrm{~mL})$ of ethanol. The mixture was stirred for about (5-10 min), then an excess of $80 \%$ hydrazine hydrate was added to the mixture and reflexed for 
(6 h). After reflexing, the mixture was poured on ice water and filtered to give a pale white precipitate. The physical properties and FTIR spectral data are listed in Table-2.

Synthesis of potassium 2-[ (benzyl thio) benzimidazole -N- (Aceto)] dithiocarbazate 1c [22]

To a stirred ethanolic solution of $\mathrm{KOH}(0.071 \mathrm{~g}, 0.0012 \mathrm{~mol}$.) in $(10 \mathrm{~mL})$ absolute ethanol, the hydrazide derivative compound $\mathbf{c}\left(0.4 \mathrm{~g}, 0.0012 \mathrm{~mol}\right.$.) then $\mathrm{CS}_{2}(0.072 \mathrm{~mL}, 0.0012 \mathrm{~mol}$.) were added slowly and stirred overnight. Later, the reaction mixture was filtered and the yellow precipitate was obtained and washed with $(20 \mathrm{~mL})$ of ether, and dried. The salt compound $1 \mathbf{c}$ was obtained in almost a quantitative yield and employed in the next step without further purification. Physical properties and FTIR spectral data for compound $\mathbf{1 c}$ are listed in Table-2.

Synthesis of 2-[(benzyl thio)benzimidazole-N-(methylene)]-4-amino-1,2,4-triazole-3-thiol 2c [22] The suspension of potassium salt $1 \mathrm{c}(0.5 \mathrm{gm}, 0.0011 \mathrm{~mol}$.) in excess hydrazine hydrate was refluxed until the evolution of $\mathrm{H}_{2} \mathrm{~S}$ was ceased. After cooling, the reaction mixture was acidified with $10 \% \mathrm{HCl}$ to yield an off-white precipitate. The precipitate was recrystallized from ethanol to give crystals. Physical properties and FTIR spectral data for compound $\mathbf{2 c}$ are listed in Table-2.

Table 2- physical properties and FTIR spectral data for compounds $4 \mathrm{~b}-2 \mathrm{c}$

\begin{tabular}{|c|c|c|c|c|c|c|c|c|c|}
\hline \multirow[b]{2}{*}{ No. } & \multirow[b]{2}{*}{$\begin{array}{c}\text { Compound } \\
\text { Structure }\end{array}$} & \multicolumn{3}{|c|}{ Physical Properties } & \multicolumn{5}{|c|}{ FTIR absorption $\mathrm{cm}^{-1}$} \\
\hline & & $\begin{array}{c}\text { M.P } \\
\mathbf{C}^{\mathbf{0}}\end{array}$ & $\begin{array}{l}\text { Yiel } \\
\text { d \% }\end{array}$ & Color & $\begin{array}{c}v(\mathrm{~N}- \\
\mathrm{H})\end{array}$ & $\begin{array}{c}v(C- \\
H) \\
\text { Arom }\end{array}$ & $\begin{array}{c}\text { v(C- } \\
\text { H) } \\
\text { Alpha }\end{array}$ & $\begin{array}{c}\mathbf{v}(\mathrm{C}= \\
\mathrm{N})\end{array}$ & other \\
\hline $4 b$ & & $\begin{array}{l}172- \\
174\end{array}$ & 85 & $\begin{array}{c}\text { Off } \\
\text { white }\end{array}$ & 3290 & 3068 & $\begin{array}{l}2964 \\
2885\end{array}$ & 1662 & $\begin{array}{l}v(\mathrm{OH}) \\
3380\end{array}$ \\
\hline $\mathbf{5 b}$ & & $\begin{array}{c}178- \\
180\end{array}$ & 73 & $\begin{array}{c}\text { Off } \\
\text { white }\end{array}$ & 3251 & 3049 & $\begin{array}{l}2964 \\
2862\end{array}$ & 1645 & $\begin{array}{c}v(\mathrm{~S}-\mathrm{H}) \\
2478\end{array}$ \\
\hline $6 \mathbf{b}$ & & $\begin{array}{c}178- \\
180\end{array}$ & 65 & $\begin{array}{c}\text { Brow } \\
\mathrm{n}\end{array}$ & & 3055 & $\begin{array}{l}2964 \\
2925 \\
2860\end{array}$ & 1647 & $\begin{array}{c}v(\mathrm{OH}) \\
3429\end{array}$ \\
\hline c & & $\begin{array}{l}134- \\
136\end{array}$ & 91 & $\begin{array}{l}\text { Pale } \\
\text { white }\end{array}$ & 3288 & 3060 & $\begin{array}{l}2958 \\
2925\end{array}$ & 1637 & $\begin{array}{c}v\left(\mathrm{NH}_{2}\right) \\
\text { Asym. } 3444 \\
\text { Sym. } 3390 \\
v(\mathrm{C}=\mathrm{O}) \\
\text { Amid } \\
1668\end{array}$ \\
\hline $1 \mathrm{c}$ & & $\begin{array}{c}168- \\
170\end{array}$ & 76 & $\begin{array}{c}\text { Off } \\
\text { white }\end{array}$ & 3222 & 2979 & $\begin{array}{l}2935 \\
2894\end{array}$ & 1629 & $\begin{array}{c}v(\mathrm{C}=\mathrm{O}) \\
\text { amid } \\
1694 \\
v(\mathrm{C}=\mathrm{S}) \\
1494\end{array}$ \\
\hline $2 c$ & & $\begin{array}{l}158- \\
160\end{array}$ & 86 & $\begin{array}{c}\text { Off } \\
\text { white }\end{array}$ & & 3064 & $\begin{array}{l}2964 \\
2925 \\
2866\end{array}$ & 1645 & $\begin{array}{c}v\left(\mathrm{NH}_{2}\right) \\
\text { Asym. } 3463 \\
\text { Sym. } 3434 \\
v(\mathrm{~S}-\mathrm{H}) 2476\end{array}$ \\
\hline
\end{tabular}




\section{Antimicrobial activities [23]}

Some of synthesized compounds were screened in vitro for their antimicrobial activities against Gram-positive and Gram-negative bacterial species as well as a fungi strain. The antibacterial activities were tested against two Gram-negative species (Acinetobacter baumannii and Pseudomonas aeruginosa) and two Gram-positive species (Staphylococcus aureus and Bacillus subtilis). The antifungal activities were tested against Candida albicans species. DMSO with dissolved tested compounds was used as a negative control. Amoxicillin and Fluconazole $(800 \mu \mathrm{g} / \mathrm{mL})$ were used as positive standards to determine the sensitivity of each microbial test. The antimicrobial activities were estimated by measuring the diameter of the zone of inhibition against the tested organisms. A stock solution of $(800 \mu \mathrm{g} / \mathrm{mL})$ was prepared by dissolving $0.004 \mathrm{~g}$ from the newly synthesized compounds in $5 \mathrm{~mL}$ DMSO. The diluted microbial culture suspension was spread on NA plates by a swab, while wells with a diameter of $8 \mathrm{~mm}$ were punched with a sterile cork borer, where $100 \mu \mathrm{L}$ of the tested compounds' solutions $(800 \mu \mathrm{g} / \mathrm{ml})$ was introduced into the holes. The inoculated plates were incubated at $37 \mathrm{C}^{0}$ for 24 hours and the resulting zones of inhibition were measured as given in Table-5.

\section{Anti-inflammatory activities [24]}

Albino rats of each six weighing $(250 \pm 50 \mathrm{gm})$ were provided by the Biotechnology Research Center, AL-Nahrain University, and housed under standardized conditions in the animal house of the Drug Control Center / Iraqi Ministry of Health. Commercial chow was used to feed the animals and they had free entry to water, ad libitum. Animals were brought to the laboratory one hour before the experiments; they were divided into five groups (six rats per group), as follows.

- Group (A): refers to the control where six rats were injected with (DMSO) with a dose of 2 $\mathrm{ml} / \mathrm{kg}$.

- Group (B): - refers to the reference substance where six rats were injected with Diclofenac Sodium with a dose of ( $3 \mathrm{mg} / \mathrm{kg})$ dissolved in DMSO.

- Group (C-E): - refers to the test where three groups, with six rats each, were injected independently with the synthesized compounds $\mathbf{3 b}, \mathbf{4 b}$ and $\mathbf{2 c}$, in doses that are determined below and equivalent to $3 \mathrm{mg} / \mathrm{kg}$ body weight of Diclofenac Sodium and dissolved in DMSO.

The anti-inflammatory activities of the synthesized compounds were tested by the paw edema method. An acute inflammation was made by the injection of $0.1 \mathrm{ml}$ fresh undiluted egg-white subcutaneously into the plantar side of the left hind paw of the rats, $30 \mathrm{~min}$ after the intraperitoneal injection of the synthesized compounds.

The paw thickness was measured by using a vernier caliper at eight time periods $(0,30,60,120,180$, 240, 300 and $360 \mathrm{~min}$ ) and these measurements were taken after the intraperitoneal injection of the synthesized compounds or the control, which was counted as time zero.

\section{Statistical analysis}

The data are expressed as the mean \pm SEM and the results were analyzed for statistical significance by using student t-test (two samples that assuming equal variance) for comparison between mean values. Probability $(\mathrm{P})$ values $<0.05$ were considered as significant.

\section{Results and Discussion}

The synthesis sequence of the preparation of 1,2,4-Triazoles derivatives from 2 mercaptobenzimidazole is shown in Scheme (1). 


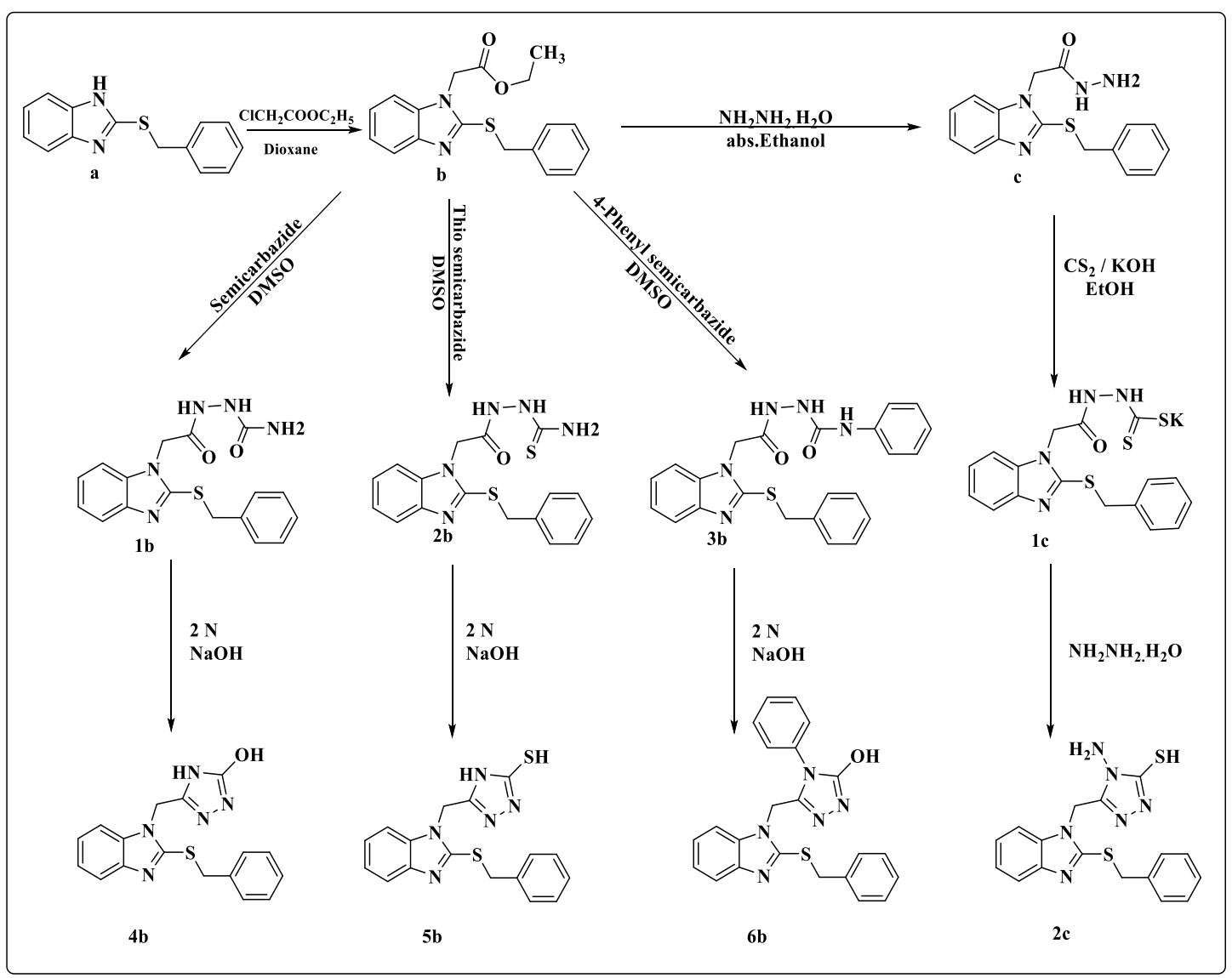

Scheme (1)

The FTIR spectrum data of compound a show absorption bands at $3134 \mathrm{~cm}^{-1}$ for stretching vibration of NH[25], $3049 \mathrm{~cm}^{-1}$ for $v$ (CH arom.), 2962, 2860 and $2808 \mathrm{~cm}^{-1}$ for $v$ (CH aliph.), $1628 \mathrm{~cm}^{-1}$ for $v$ $(\mathrm{C}=\mathrm{N}$ imidazole $)$, and 1512 for $v(\mathrm{C}=\mathrm{C}$ arom.). While The FTIR spectrum data of compound $\mathbf{b}$ show the disappearance of the absorption band $3134 \mathrm{~cm}^{-1}$ that belongs to $v(-\mathrm{NH})$, with new absorption bands that appeared at $1753 \mathrm{~cm}^{-1}$ for $v(\mathrm{C}=\mathrm{O})$ and $1207 \mathrm{~cm}^{-1}$ for $v(\mathrm{C}-\mathrm{O})$, which belong to ester. The FTIR spectrum data of compounds $\mathbf{a}$ and $\mathbf{b}$ are listed in Table-1.

Compound $\mathbf{b}$ was converted to Semicarbazide $\mathbf{1 b}$, Thiosemicarbazide $\mathbf{2 b}$, phenylsemicarbazide $\mathbf{3 b}$ and hydrazide $\mathbf{c}$ derivatives by the reaction of compound $\mathbf{b}$ with Semicarbazide, Thiosemicarbazide and Phenylsemicarbazide, and in DMSO or hydrazine hydrate in EtOH as solvents, respectively. The FTIR spectral data of compounds $\mathbf{1 b}-\mathbf{3 b}$ show the disappearance of the absorption band at $1753 \mathrm{~cm}^{-1}$, which belongs to $v(\mathrm{C}=\mathrm{O})$ of the ester. There is a new absorption band at $1695-1664 \mathrm{~cm}^{-1}$ which belongs to $v$ $(\mathrm{C}=\mathrm{O})$ of the amid band (1) [26]. There are also new absorption bands at $3468-3438 \mathrm{~cm}^{-1}$ and $3417-$ $3398 \mathrm{~cm}^{-1}$ which belong to $v\left(\mathrm{NH}_{2}\right)$ Asym. and Sym., respectively. There are also absorption bands at 3255-3232 $\mathrm{cm}^{-1}$ which belongs to $v(\mathrm{NH})$, at $3066 \mathrm{~cm}^{-1}$ which belongs to $v(\mathrm{CH})$ aromatic, and at $1650-1620 \mathrm{~cm}^{-1}$ which belongs to $v(\mathrm{C}=\mathrm{N})$ of imidazole ring. The FTIR spectral data of compounds $\mathbf{1 b - 3 b}$ are listed in Table-1.

The ${ }^{1} \mathrm{H}$-NMR spectral data of compound $\mathbf{3 b}$ show a singlet signal at $\delta=4.58 \mathrm{ppm}$ which belongs to $2 \mathrm{H}$ due to $\left(-\mathrm{SCH}_{2}\right)$, a new singlet signal at $\delta=4.72 \mathrm{ppm}$ which belongs to $1 \mathrm{H}$ due to $(\mathrm{NH}-\mathrm{Ar})$, a singlet signal at $\delta=5.31 \mathrm{ppm}$ which belongs to $2 \mathrm{H}$ due to $\left(-\mathrm{NCH}_{2}\right)$, a multiplet signal at $\delta=7.13-7.46 \mathrm{ppm}$ which belongs to $14 \mathrm{H}$ due to $(\mathrm{Ar}-\mathrm{H})$, a new singlet signal at $\delta=9.10 \mathrm{ppm}$ which belongs to $1 \mathrm{H}$ due to (CO-NH-N), and a new singlet signal at $\delta=12.4 \mathrm{ppm}$ which belongs to $2 \mathrm{H}$ due to (CO-NH-NH -CO). The ${ }^{1} \mathrm{H}-\mathrm{NMR}$ spectral data of compound $\mathbf{3 b}$ are listed in Table-3.

The ${ }^{13} \mathrm{C}-\mathrm{NMR}$ spectral data of compound $\mathbf{3 b}$ show a signal at $\delta=38.67 \mathrm{ppm}$ which belongs to $\left(-\mathrm{SCH}_{2}\right)$, a singlet signal at $\delta=120.87 \mathrm{ppm}$ which belongs to $\left(-\mathrm{NCH}_{2}\right)$, a singlet signal at $\delta=126.77-128.30 \mathrm{ppm}$ which belongs to $(\mathrm{Ar})$, a singlet at $\delta=149.15 \mathrm{ppm}$ due to $(\mathrm{C}=\mathrm{N})$ of imidazole ring, a signal at $\delta=163.15 \mathrm{ppm}$ due to $(\mathrm{C}=\mathrm{O})$ of amide, and a signal at $\delta=168.49 \mathrm{ppm}$ due to $(\mathrm{N}-\mathrm{CO}-\mathrm{N})$. The ${ }^{13} \mathrm{C}-\mathrm{NMR}$ spectral data of compound $\mathbf{3 b}$ are listed in Table-3. 
Table 3-The ${ }^{1} \mathrm{H}-\mathrm{NMR}$ and ${ }^{13} \mathrm{C}-\mathrm{NMR}$ spectral data of compound $\mathbf{3 b}$

\begin{tabular}{|c|c|c|c|}
\hline $\begin{array}{l}\text { Com. } \\
\text { NO. }\end{array}$ & Structure & $\begin{array}{c}{ }^{1} \text { H-NMR spectral data } \\
(\delta \text { ppm })\end{array}$ & $\begin{array}{c}{ }^{13} \text { C-NMR spectral data } \\
(\delta \text { ppm })\end{array}$ \\
\hline $\mathbf{3 b}$ & & $\begin{array}{c}4.58\left(\mathrm{~s}, 2 \mathrm{H}, \mathrm{S}-\mathrm{CH}_{2}\right) ; 4.72(\mathrm{~s} \\
1 \mathrm{H}, \mathrm{NH}-\mathrm{Ar}) ; 5.31(\mathrm{~s}, 2 \mathrm{H}, \mathrm{N}- \\
\left.\mathrm{CH}_{2}\right) ; 7.13-7.46(\mathrm{~m}, 9 \mathrm{H}, \mathrm{Ar}- \\
\mathrm{H}) ; 9.10(\mathrm{~s}, 1 \mathrm{H}, \mathrm{CO}-\mathrm{NH}-\mathrm{N}) ; \\
12.4(\mathrm{~s}, 1 \mathrm{H}, \mathrm{CO}-\mathrm{NH} \mathrm{NH}- \\
\mathrm{CO}) .\end{array}$ & $\begin{array}{c}38.67\left(\mathrm{~S}-\mathrm{CH}_{2}\right) ; 120.87(\mathrm{~N}- \\
\left.\mathrm{CH}_{2}\right) ; 126.77-128.30(\mathrm{Ar}) \\
149.15(\mathrm{C}=\mathrm{N} \text { imidazole }) \\
163.15(\mathrm{C}=\mathrm{O}) ; 168.49(\mathrm{~N}-\mathrm{CO}- \\
\mathrm{N})\end{array}$ \\
\hline
\end{tabular}

Compounds $\mathbf{1 b}$-3b were converted to 1,2,4-Triazole derivatives by a cyclization reaction via reflexing with $(2 \mathrm{~N}) \mathrm{NaOH}$ to yield 1,2,4-Triazole derivative compounds $\mathbf{4 b} \mathbf{b}-\mathbf{6} \mathbf{b}$.

The FTIR spectral data of compounds $\mathbf{4 b - 6 b}$ show that there was a disappearance of the absorption bands 3468-3438 $\mathrm{cm}^{-1}$ and 3417-3398 $\mathrm{cm}^{-1}$ due to $v\left(\mathrm{NH}_{2}\right)$ Asym. and Sym., respectively. Instead of that, there was an appearance of a new band at 3429-3380 $\mathrm{cm}^{-1}$ which belongs to $v(\mathrm{OH})$ for compounds $4 \mathbf{b}, \mathbf{6} \mathbf{b}$ and $2478 \mathrm{~cm}^{-1}$ which belongs to $v(\mathrm{SH})$ for compound $\mathbf{5 b}$. The remaining absorption bands are at 3290-3251 $\mathrm{cm}^{-1}$ which belongs to $v(\mathrm{NH})$, at 3068-3049 $\mathrm{cm}^{-1}$ which belongs to $v(\mathrm{CH})$ Aromatic, at 2964-2860 $\mathrm{cm}^{-1}$ which belongs to $v(\mathrm{CH})$ Aliphatic, at $1662-1645 \mathrm{~cm}^{-1}$ which belongs to $(\mathrm{C}=\mathrm{N})$, and at $1591-1541 \mathrm{~cm}^{-1}$ which belongs to $(\mathrm{C}=\mathrm{C})$ Aromatic. The FTIR spectral data of

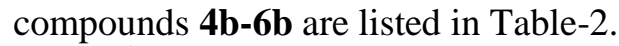

The ${ }^{1} \mathrm{H}-\mathrm{NMR}$ results of compound $\mathbf{4 b}$ show a new singlet signal at $\delta=12.4 \mathrm{ppm}$ due to $1 \mathrm{H}$ which belongs to (-NH) of triazole ring, while the singlet signal at $\delta=3.51 \mathrm{ppm}$ is due to $2 \mathrm{H}$ and belongs to ($\left.\mathrm{SCH}_{2}\right)$, the singlet signal at $\delta=4.48 \mathrm{ppm}$ belongs to $2 \mathrm{H}\left(-\mathrm{NCH}_{2}\right)$, the multiplet at $\delta=7.14-7.46 \mathrm{ppm}$ is for $9 \mathrm{H}(\mathrm{Ar}-\mathrm{H})$, and the singlet signal at $\delta=9.84 \mathrm{ppm}$ belongs to $1 \mathrm{H}$ for $(-\mathrm{OH})$. The ${ }^{1} \mathrm{H}-\mathrm{NMR}$ and The ${ }^{13} \mathrm{C}-\mathrm{NMR}$ spectral data of compound $\mathbf{4 b}$ are listed in Table- 4 .

While the ${ }^{1} \mathrm{H}-\mathrm{NMR}$ results of compound $\mathbf{6 b}$ show a singlet signal at $\delta=3.50 \mathrm{ppm}$ which belongs to $2 \mathrm{H}$ of $\left(-\mathrm{SCH}_{2}\right)$, a singlet signal at $\delta=4.58 \mathrm{ppm}$ which belongs to $2 \mathrm{H}\left(-\mathrm{NCH}_{2}\right)$, a multiplet signal at $\delta=$ 6.97-7.46 ppm which belongs to $14 \mathrm{H}$ for $(\mathrm{Ar}-\mathrm{H})$, and a singlet signal at $\delta=8.79 \mathrm{ppm}$ due to $1 \mathrm{H}$ for ($\mathrm{OH})$. The ${ }^{1} \mathrm{H}-\mathrm{NMR}$ and The ${ }^{13} \mathrm{C}-\mathrm{NMR}$ spectral data of compound $\mathbf{6} \mathbf{b}$ are listed in Table-4.

Table 4-The ${ }^{1} \mathrm{H}-\mathrm{NMR}$ and ${ }^{13} \mathrm{C}-\mathrm{NMR}$ spectral data of compounds $4 \mathbf{b}-\mathbf{6} \mathbf{b}$

\begin{tabular}{|c|c|c|c|}
\hline $\begin{array}{l}\text { Com. } \\
\text { NO. }\end{array}$ & Structure & ${ }^{1} \mathrm{H}-\mathrm{NMR}$ spectral data ( $\left.\delta \mathrm{ppm}\right)$ & $\begin{array}{c}{ }^{13} \mathrm{C}-\mathrm{NMR} \text { spectral data } \\
(\delta \mathrm{ppm})\end{array}$ \\
\hline $4 b$ & & $\begin{array}{c}3.51\left(\mathrm{~s}, 2 \mathrm{H}, \mathrm{S}-\mathrm{CH}_{2}\right) ; 4.48(\mathrm{~s}, 2 \mathrm{H} \\
\left.\mathrm{N}-\mathrm{CH}_{2}\right) ; 7.14-7.46(\mathrm{~m}, 9 \mathrm{H}, \mathrm{Ar}- \\
\mathrm{H}) ; 9.84(\mathrm{~s}, 1 \mathrm{H}, \mathrm{OH}) ; 12.4(\mathrm{~s}, 1 \mathrm{H} \\
\mathrm{NH} \text { triazole })\end{array}$ & $\begin{array}{c}38.73\left(\mathrm{~S}-\mathrm{CH}_{2}\right) ; 113.28\left(\mathrm{~N}^{-} \mathrm{CH}_{2}\right) ; \\
126.76-128.28(\mathrm{Ar}) ; 137.10 \\
(\mathrm{C}=\mathrm{N} \text { triazole); } 149.15(\mathrm{C}=\mathrm{N} \\
\text { imidazole }) .\end{array}$ \\
\hline $6 \mathbf{b}$ & & $\begin{array}{c}3.50\left(\mathrm{~s}, 2 \mathrm{H}, \mathrm{S}-\mathrm{CH}_{2}\right) ; 4.58(\mathrm{~s} \\
\left.2 \mathrm{H}, \mathrm{N}-\mathrm{CH}_{2}\right) ; 6.97-7.46(\mathrm{~m}, 9 \mathrm{H} \\
\operatorname{Ar}-\mathrm{H}) ; 8.79(\mathrm{~s}, 1 \mathrm{H}, \mathrm{OH}) .\end{array}$ & $\begin{array}{c}38.66\left(\mathrm{~S}-\mathrm{CH}_{2}\right) ; 117.59\left(\mathrm{~N}-\mathrm{CH}_{2}\right) ; \\
126.77 \text {-128.30 }(\mathrm{Ar}) ; 137.13 \\
(\mathrm{C}=\mathrm{N} \text { triazole }) ; 149.17(\mathrm{C}=\mathrm{N} \\
\text { imidazole }) .\end{array}$ \\
\hline
\end{tabular}

Compound 10 was synthesized by the reaction of hydrazide compound $\mathbf{c}$ with $\mathrm{CS}_{2}$ in ethanolic $\mathrm{KOH}$ to give the dithiocarbazate salt $\mathbf{1 c}$ in an excellent yield, which was then cyclized by refluxing with hydrazine hydrate to give a good yield of Triazole derivative 2c.

The FTIR spectrum data of compound 1c show absorption bands at $3222 \mathrm{~cm}^{-1}$ which belongs to $v$ $(\mathrm{NH})$, at $2979 \mathrm{~cm}^{-1}$ which belongs to $v(\mathrm{CH})$ Aromatic, at 2935-2984 $\mathrm{cm}^{-1}$ which belongs to $v(\mathrm{CH})$ Aliphatic, and at $1629 \mathrm{~cm}^{-1}$ which belongs to $v(\mathrm{C}=\mathrm{N})$ imidazole ring. While compound $2 \mathrm{c}$ shows two absorption bands at $3463 ; 3434 \mathrm{~cm}^{-1}$ which belongs to $v\left(\mathrm{NH}_{2}\right)$ Asym. and Sym, respectively, as well as bands at $3064 \mathrm{~cm}^{-1}$ which belongs to $v(\mathrm{C}-\mathrm{H})$ Aromatic, at $2476 \mathrm{~cm}^{-1}$ which belongs to $v(\mathrm{~S}-\mathrm{H})$, and at $1645 \mathrm{~cm}^{-1}$ which belongs to $v(\mathrm{C}=\mathrm{N})[27]$. The FTIR spectrum data of compounds 1c-2c are shown in Table-2. 
The ${ }^{1} \mathrm{H}-\mathrm{NMR}$ spectral data of compound $\mathbf{2 c}$ show a singlet signal at $\delta=3.28 \mathrm{ppm}$ which belongs to $1 \mathrm{H}$ due to (-SH), a singlet signal at $\delta=4.09 \mathrm{ppm}$ which belongs to $2 \mathrm{H}$ for $\left(-\mathrm{SCH}_{2}\right)$, a signal at $\delta=4.57 \mathrm{ppm}$ which belongs to $2 \mathrm{H}$ of $\left(-\mathrm{NH}_{2}\right)$, a signal at $\delta=5.25 \mathrm{ppm}$ which belongs to $2 \mathrm{H}$ for $\left(-\mathrm{NCH}_{2}\right)$, and a multiplet signal at $\delta=7.08-7.44 \mathrm{ppm}$ which belongs to $9 \mathrm{H}$ of $(\mathrm{Ar}-\mathrm{H})$. The ${ }^{13} \mathrm{C}-\mathrm{NMR}$ spectral data of compound 2c show a signal at $\delta=38.69 \mathrm{ppm}$ which belongs to $\left(-\mathrm{SCH}_{2}\right)$, a signal at $\delta=117.28 \mathrm{ppm}$ which belongs to $\left(-\mathrm{NCH}_{2}\right)$, a multiplet signal at $\delta=126.76-128.28 \mathrm{ppm}$ which belongs to (Ar), a signal at $\delta=149.26 \mathrm{ppm}$ which belongs to $(\mathrm{C}=\mathrm{N})$ triazole ring, and a signal at $\delta=158.28 \mathrm{ppm}$ which belongs to $(\mathrm{C}=\mathrm{N})$ imidazole ring. The ${ }^{1} \mathrm{H}-\mathrm{NMR}$ and The ${ }^{13} \mathrm{C}-\mathrm{NMR}$ spectral data of compound $2 \mathrm{c}$ are listed in Table-5.

Table 5-The ${ }^{1} \mathrm{H}-\mathrm{NMR}$ and ${ }^{13} \mathrm{C}-\mathrm{NMR}$ spectral data of compound $\mathbf{2 c}$

\begin{tabular}{|c|c|c|c|}
\hline $\begin{array}{l}\text { Com. } \\
\text { NO. }\end{array}$ & Structure & ${ }^{1} \mathrm{H}-\mathrm{NMR}$ spectral data ( $\left.\delta \mathrm{ppm}\right)$ & ${ }^{13} \mathrm{C}-\mathrm{NMR}$ spectral data ( $\left.\delta \mathrm{ppm}\right)$ \\
\hline $2 c$ & & $\begin{array}{c}3.28(\mathrm{~s}, 1 \mathrm{H}, \mathrm{SH}) ; 4.09(\mathrm{~s}, 2 \mathrm{H}, \mathrm{S}- \\
\left.\mathrm{CH}_{2}\right) ; 4.57\left(\mathrm{~s}, 2 \mathrm{H}, \mathrm{NH}_{2}\right) 5.25(\mathrm{~s} \\
\left.2 \mathrm{H}, \mathrm{N}-\mathrm{CH}_{2}\right) ; 7.08-7.44(\mathrm{~m}, 9 \mathrm{H}, \\
\text { Ar-H). }\end{array}$ & $\begin{array}{r}38.69\left(\mathrm{~S}-\mathrm{CH}_{2}\right) ; 117.28\left(\mathrm{~N}-\mathrm{CH}_{2}\right) ; \\
126.76-128.28(\mathrm{Ar}) ; 149.26(\mathrm{C}=\mathrm{N} \\
\text { triazole }) ; 158.28(\mathrm{C}=\mathrm{N} \text { imidazole }) .\end{array}$ \\
\hline
\end{tabular}

Anti-microbial Activity

Some of 2-mercaptobenzimidazole derivatives (semicarbazide, thiosemicarbazide, phenylsemicarbazide and 1,2,4-triazole derivatives) were screened for anti-microbial activities against two Gram positive (Staphylococcus aureus and Bacillus Subtilis) and two Gram negative (Pseudomonas aeruginosa and Acinetobacter baumannii) bacteria and one strain of fungi (Candida albicans). The results showed that compounds $\mathbf{3 b}$ and $\mathbf{2 c}$ have a moderate to good activity against all species of Gram negative and positive bacteria, but were not effective against the fungal species. While compounds $\mathbf{c}, \mathbf{1 b}$ and $\mathbf{2 b}$ have a good activity against fungus but not effective against all species of bacteria . Compound b was only sensitive against Gram positive bacteria (Bacillus Subtilis) and against the fungus, whereas compound $\mathbf{6 b}$ was not effective against Gram negative bacteria (Acinetobacter baumannii). Compound $\mathbf{5 b}$ was not effective against all bacterial and fungal species, as shown in Table-6.

Table 6-Results of anti-microbial activity tests of some prepared compounds

\begin{tabular}{|c|c|c|c|c|c|}
\hline \multirow{2}{*}{$\begin{array}{c}\text { No. of comp. } \\
\text { and standard } \\
(\mathbf{8 0 0} \boldsymbol{\mu g} / \mathbf{m l})\end{array}$} & $\begin{array}{c}\text { Staphylococcus } \\
\text { aureus }\end{array}$ & $\begin{array}{c}\text { Pseudomonas } \\
\text { aeruginosa }\end{array}$ & $\begin{array}{c}\text { Bacillus } \\
\text { subtilis }\end{array}$ & $\begin{array}{c}\text { Acinetobacter } \\
\text { baumannii }\end{array}$ & $\begin{array}{c}\text { Candida } \\
\text { Albicans }\end{array}$ \\
\cline { 2 - 7 } $\mathbf{C}$ & - & - & - & - & - \\
\hline $\mathbf{b}$ & - & - & 12 & - & 20 \\
\hline $\mathbf{c}$ & - & - & - & - & 18 \\
\hline $\mathbf{1 b}$ & - & - & - & - & 19 \\
\hline $\mathbf{2 b}$ & - & - & - & - & 16 \\
\hline $\mathbf{3 b}$ & 20 & 21 & 18 & 11 & - \\
\hline $\mathbf{4 b}$ & 18 & 14 & 15 & - & 10 \\
\hline $\mathbf{5 b}$ & - & - & - & - & - \\
\hline $\mathbf{6 b}$ & 19 & 11 & 12 & - & 11 \\
\hline $\mathbf{2 c}$ & 17 & 15 & 14 & 12 & - \\
\hline Amoxicillin & 33 & 32 & 33 & - & - \\
\hline Fluconazole & - & - & - & - & 25 \\
\hline
\end{tabular}

[Control]: $800 \mu \mathrm{g} / \mathrm{ml}$; Solvent: dimethylsolfoxide

Inhibition Zone: (-) no inhibition; (6-10) weak; (11-18) moderate; (19-30) strong; (30>) very strong. 


\section{Anti-inflammatory activities}

The Anti-inflammatory activities of the final target compounds (3b, $\mathbf{4 b}$ and $\mathbf{2 c})$ were testes using the paw edema method, where an acute inflammation was made by the injection of fresh undiluted egg-white subcutaneously into the plantar side of the left hind paw of Wistar albino rats.

To consider the rationality of this method, the reference compound used to recognize the antiinflammatory activity profile was Diclofenac Sodium. The tested compounds $(\mathbf{3 b}, \mathbf{4 b}$ and $\mathbf{2 c})$ and the reference drug (Diclofenac Sodium) produced a significant reduction in paw edema thickness as compared to the effect of dimethyl sulfoxide (DMSO), which is used in the control group. The results of the anti-inflammatory activity of the reference and the control are shown in Table-7.

Since $\mathrm{p}$ value is $<0.05$ by comparing both control (DMSO) and reference (Diclofenac Sodium) groups, this indicates that the paw edema method used in this work is an effective method and can successfully be used for the assessment of the anti-inflammatory effects of the synthesized compounds, as shown in Figure-1.

The results of the anti-inflammatory effects of the tested compounds $(\mathbf{3 b}, \mathbf{4 b}$ and $\mathbf{2 c})$ in comparison to the reference (diclofenac sodium) group and the control (DMSO) group are revealed in Table- 8 . All the tested compounds $(\mathbf{3 b}, \mathbf{4 b}$ and $\mathbf{2 c}$ ) effectively limited the increase of the volume of paw edema. The effects of the synthesized compounds started at 120 minutes, a result which is significantly different as compared to the control), and continued till the end of the experiment, with statistically significant reduction ( $\mathrm{p}$ value less than 0.05 ) in the thickness of paw edema, as shown in Figure-2.

Table 7-The effects of diclofenac sodium (reference) and dimethyl sulfoxide (control) on the fresh egg white-induced paw edema inflammation in rats

\begin{tabular}{|c|c|c|c|}
\hline \multirow{9}{*}{ 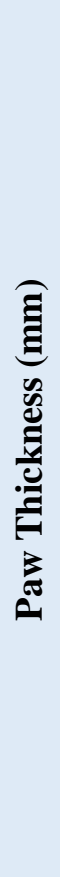 } & $\begin{array}{l}\text { Time } \\
\text { (min) }\end{array}$ & $\begin{array}{c}\text { DMSO } \\
(\mathbf{n}=6)\end{array}$ & $\begin{array}{c}\text { Diclofenac Sodium } \\
(n=6)\end{array}$ \\
\hline & 0 & $3.73 \pm 0.14$ & $3.71 \pm 0.23$ \\
\hline & 30 & $5.59 \pm 0.24$ & $5.42 \pm 0.22$ \\
\hline & 60 & $6.85 \pm 0.10$ & $6.51 \pm 0.16^{*}$ \\
\hline & 120 & $6.43 \pm 0.21$ & $6.25 \pm 0.17 *$ \\
\hline & 180 & $6.55 \pm 0.11$ & $6.10 \pm 0.13 *$ \\
\hline & 240 & $5.55 \pm 0.10$ & $5.49 \pm 0.24$ \\
\hline & 300 & $5.40 \pm 0.21$ & $4.98 \pm 0.24 *$ \\
\hline & 360 & $5.26 \pm 0.16$ & $4.71 \pm 0.15^{*}$ \\
\hline
\end{tabular}

Data are stated in (mm) paw thickness as (mean \pm SEM).

$\mathrm{n}=$ number of animals.

Time (0) is the time of i.p. injection of Diclofenac Sodium (reference) and DMSO (control).

Time (30) is the time of injection of fresh egg-white for induction of paw edema.

$*$ Significantly different compared to control: p-value $*<0.05$. 
Table 8-The effects of control, diclofenac sodium and tested compounds $3 b, 4 b$ and $2 c$ on eggwhiteinduced paw edema inflammation in rats

\begin{tabular}{|c|c|c|c|c|c|}
\hline $\begin{array}{c}\text { Time } \\
(\mathbf{m i n})\end{array}$ & $\begin{array}{c}\text { DMSO } \\
(\mathbf{n}=6)\end{array}$ & $\begin{array}{c}\text { Diclofenac Sodium } \\
(\mathbf{n}=\mathbf{6})\end{array}$ & $\begin{array}{c}\text { Compound } \\
\mathbf{3 b} \\
(\mathbf{n}=\mathbf{6})\end{array}$ & $\begin{array}{c}\text { Compound } \\
\mathbf{4 b} \\
(\mathbf{n}=6)\end{array}$ & $\begin{array}{c}\text { Compound 2c } \\
(\mathbf{n = 6})\end{array}$ \\
\hline 0 & $3.73 \pm 0.14$ & $3.71 \pm 0.23$ & $4.36 \pm 0.14$ & $3.68 \pm 0.12$ & $3.54 \pm 0.13$ \\
\hline 30 & $5.59 \pm 0.24$ & $5.42 \pm 0.22$ & $5.32 \pm 0.21$ & $5.46 \pm 0.10$ & $5.51 \pm 0.04$ \\
\hline 60 & $6.85 \pm 0.10$ & $6.51 \pm 0.16^{\mathrm{a}}$ & $6.55 \pm 0.06^{\mathrm{a}}$ & $5.67 \pm 0.21^{\mathrm{b}}$ & $5.54 \pm 0.08^{\mathrm{b}}$ \\
\hline 120 & $6.43 \pm 0.21$ & $6.25 \pm 0.17^{\mathrm{a}}$ & $6.58 \pm 0.10^{\mathrm{a}}$ & $5.34 \pm 0.09^{\mathrm{b}}$ & $5.55 \pm 0.23^{\mathrm{b}}$ \\
\hline 180 & $6.55 \pm 0.11$ & $6.10 \pm 0.13^{\mathrm{a}}$ & $5.92 \pm 0.17^{\mathrm{a}}$ & $5.12 \pm 0.12^{\mathrm{b}}$ & $5.50 \pm 0.11^{\mathrm{b}}$ \\
\hline 240 & $5.55 \pm 0.10$ & $5.49 \pm 0.24$ & $5.49 \pm 0.08^{\mathrm{a}}$ & $4.82 \pm 0.04^{\mathrm{b}}$ & $5.13 \pm 0.16^{\mathrm{a}}$ \\
\hline 300 & $5.40 \pm 0.21$ & $4.98 \pm 0.24^{\mathrm{a}}$ & $5.19 \pm 0.05^{\mathrm{a}}$ & $4.55 \pm 0.04^{\mathrm{b}}$ & $4.82 \pm 0.22^{\mathrm{a}}$ \\
\hline 360 & $5.26 \pm 0.16$ & $4.71 \pm 0.15^{\mathrm{a}}$ & $5.12 \pm 0.12^{\mathrm{a}}$ & $4.22 \pm 0.11^{\mathrm{b}}$ & $4.72 \pm 0.07^{\mathrm{a}}$ \\
\hline
\end{tabular}

Data are stated in $(\mathrm{mm})$ paw thickness as (mean $\pm \mathrm{SEM})$.

$\mathrm{n}=$ number of animals.

Time (0) is the time of i.p. injection of tested compounds, Diclofenac Sodium and DMSO (control).

Time (30) is the time of injection of fresh egg-white (induction of paw edema).

Non-identical superscripts ( $a$ and $b$ ) among different groups are considered significantly different $p$ value $<0.05$.

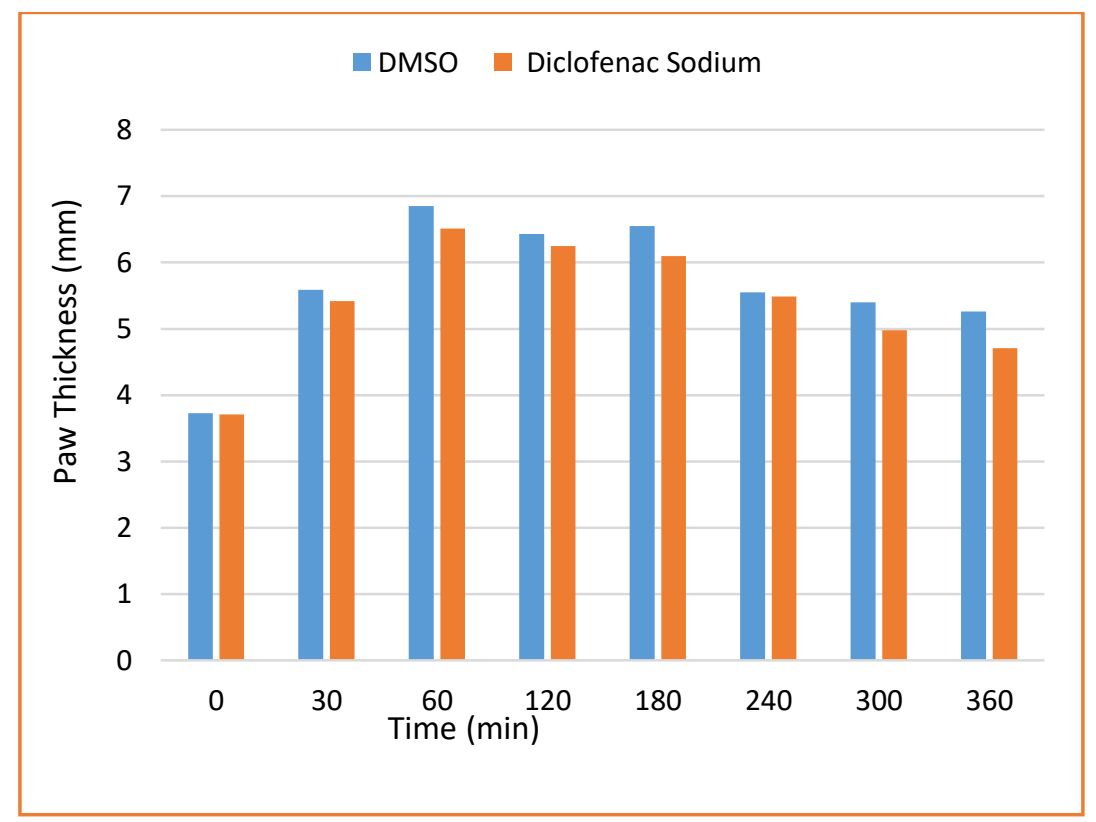

Figure 1-The effect of Diclofenac Sodium and dimethyl sulfoxide on the fresh egg-white induced paw edema in rats Time (30) is the time of egg-white injection 


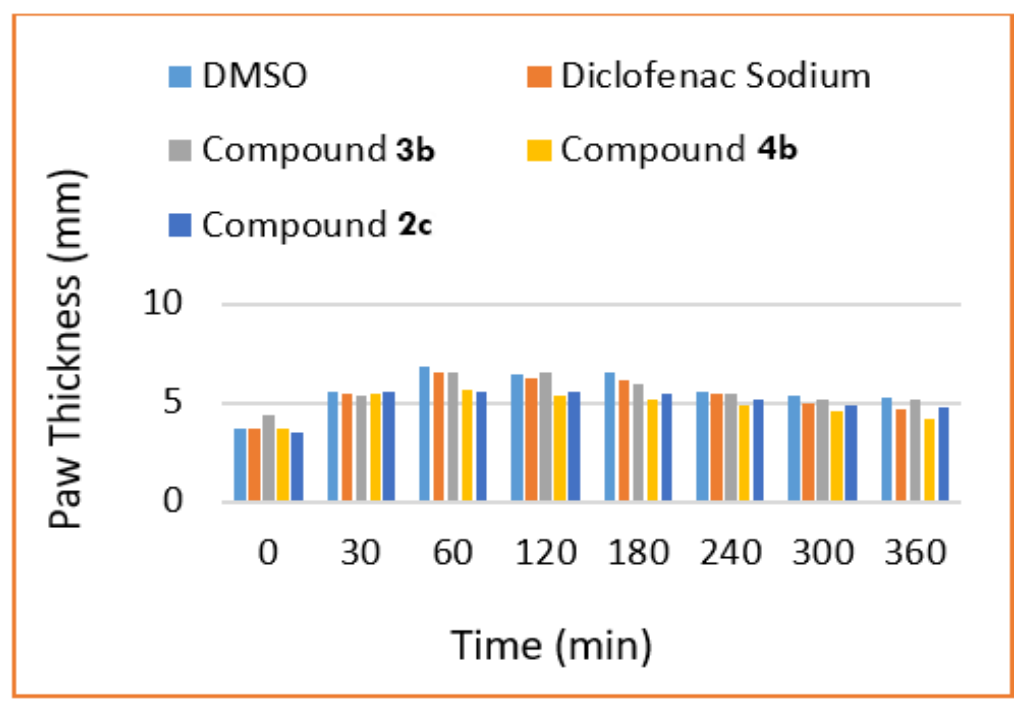

Figure 2-The effect of Diclofenac Sodium, dimethyl sulfoxide, compounds 3b, $4 b$ and $2 c$ on the eggwhite induced paw edema in rats

\section{References}

1. Abraham, R.; Prakash, P.; Mahendran, K. and Ramanathan, M., 2018,A novel series of N-acyl substituted indole-linked benzimidazoles and naphthoimidazoles as potential anti inflammatory, anti biofilm and anti microbial agents. Microbial pathogenesis, 114: 409-413.

2. Gaba, M.; Singh, D.; Singh, S.; Sharma, V. and Gaba, P., 2010,Synthesis and pharmacological evaluation of novel 5-substituted-1-(phenylsulfonyl)-2-methylbenzimidazole derivatives as antiinflammatory and analgesic agents. European journal of medicinal chemistry 45(6): 2245-2249.

3. Yadav, S. and Narasimhan, B., 2016,Perspectives of benzimidazole derivatives as anticancer agents in the new era. Anti-Cancer Agents in Medicinal Chemistry (Formerly Current Medicinal Chemistry-Anti-Cancer Agents), 16(11): 1403-1425.

4. Anand, K. and Wakode, S., 2017,Development of drugs based on Benzimidazole Heterocycle: Recent advancement and insights. International Journal of Chemical Studies, 5(2): 350-362.

5. Katiyar, A.; Rai, J.; Gangwar, S.; Mohanty, A. K. and Mishra, A. P. 2018. Biological Activities of Substituted Benzimidazole Derivatives. Journal of Drug Discovery and Development, 2(1): 2-10.

6. Mavrova, A. T.; Yancheva, D.; Anastassova, N.; Anichina, K.; Zvezdanovic, J.; Djordjevic, A.; Markovic, D. and Smelcerovic, A. 2015. Synthesis, electronic properties, antioxidant and antibacterial activity of some new benzimidazoles. Bioorganic \& Medicinal Chemistry, 23(19): 6317-6326.

7. Özkay, Y.; Tunalı, Y.; Karaca, H. and Işıkdağ, İ. 2010. Antimicrobial activity and a SAR study of some novel benzimidazole derivatives bearing hydrazone moiety. European journal of medicinal chemistry, 45(8): 3293-3298.

8. Gultekin, E.; Kolcuoglu, Y.; Akdemir, A.; Sirin, Y.; Bektas, H. and Bekircan, O. 2018. A Study On Synthesis, Biological Activities and Molecular Modelling of Some Novel Trisubstituted 1, 2, 4-Triazole Derivatives. ChemistrySelect, 3(31): 8813-8818.

9. Al-Azzawi, A. M. and Hammud, K. K., 2013,Synthesis and Characterization of Some New 1, 3, 4-Oxadiazole and 1, 2, 4-Triazole Derivatives Based on 3, 4, 5, 6 Tetrachlorophthalimide. Iraqi Journal of Science, 54(4): 782-788.

10. Ahirwar, J.; Ahirwar, D.; Lanjhiyana, S.; Jha, A.; Dewangan, D. and Badwaik, H. 2018. Analgesic and Anti-inflammatory Potential of Merged Pharmacophore Containing 1, 2, 4-triazoles and Substituted Benzyl Groups via Thio Linkage. Journal of Heterocyclic Chemistry, 55(9): 21302141.

11. Jin, R.; Liu, J.; Zhang, G.; Li, J.; Zhang, S. and Guo, H. 2018. Design, Synthesis, and Antifungal Activities of Novel 1, 2, 4-Triazole Schiff Base Derivatives. Chemistry \& biodiversity, 15(9): e1800263.

12. Gao, F.; Wang, T.; Xiao, J. and Huang, G. 2019. Antibacterial activity study of 1, 2, 4-triazole derivatives. European journal of medicinal chemistry, 173: 274-281. 
13. Al-Khuzaie, M. G. and Al-Majidi, S. M. 2014. Synthesis, characterization and evaluation antimicrobial activity of some new substituted 2-mercapto-3-phenyl-4 $(3 \mathrm{H})$-quinazolinone. Iraqi Journal of Science, 55(2Supplement): 582-593.

14. Sari, S.; Kaynak, F. B. and Dalkara, S. 2018. Synthesis and anticonvulsant screening of 1, 2, 4triazole derivatives. Pharmacological Reports, 70(6): 1116-1123.

15. Arif, M. N.; Nadeem, H.; Paracha, R. Z.; Khan, A.-u.; Imran, M. and Ali, F. 2019. Synthesis, Anti-inflammatory, Antimicrobial Potential and Molecular Docking Studies of 4, 5-Disubstituted1, 2, 4-Triazole Thioacetate Derivatives. Letters in Drug Design \& Discovery, 16(7): 734-745.

16. Chen, Y.; Li, P.; Su, S.; Chen, M.; He, J.; Liu, L.; He, M.; Wang, H. and Xue, W. 2019. Synthesis and antibacterial and antiviral activities of myricetin derivatives containing a 1, 2, 4-triazole Schiff base. RSC Advances, 9(40): 23045-23052.

17. Chu, X.-M.; Wang, C.; Wang, W.-L.; Liang, L.-L.; Liu, W.; Gong, K.-K. and Sun, K.-L. 2019. Triazole derivatives and their antiplasmodial and antimalarial activities. European journal of medicinal chemistry, 166: 206-223.

18. Basoglu Ozdemir, S.; Demirbas, N.; Demirbas, A.; Ayaz, F. A. and Çolak, N. 2018. MicrowaveAssisted Synthesis, Antioxidant, and Antimicrobial Evaluation of Piperazine-AzoleFluoroquinolone Based 1, 2, 4-Triazole Derivatives. Journal of Heterocyclic Chemistry, 55(12): 2744-2759.

19. Suaad M. H. Al-Majidi; Hala A. M. Rasheed and Suhad F. H. Al-Mugdadi. 2015. Synthesis, Identification and Evaluation of Antimicrobial Activities of some New N-substituted 2azetidinone, Imidazolidinone and tetrazole derivatives of 2-(methylthio) benzimidazole. International Journal of Science and Research, 6(6): 1009 -1016

20. Suaad M. H. Al-Majidi, 2013,Synthesis, Characterization and Evaluation of Antimicrobial Activity of Several New N-Substituted Carbazole. Al-Nahrain Journal of Science, 16(4): 67-79.

21. Song, M.; Wang, S.; Wang, Z.; Fu, Z.; Zhou, S.; Cheng, H.; Liang, Z. and Deng, X. 2019. Synthesis, antimicrobial and cytotoxic activities, and molecular docking studies of $\mathrm{N}$ arylsulfonylindoles containing an aminoguanidine, a semicarbazide, and a thiosemicarbazide moiety. European journal of medicinal chemistry, 166: 108-118.

22. Udupi, R. and Manjunath, C. 2019. Synthesis and Biological Evaluation of certain N-bridged 1, 2, 4-Triazole analogues. Journal of Pharmaceutical Sciences and Research, 11(1): 44-49.

23. Qin, Y.; Xiong, L.; Li, M.; Liu, J.; Wu, H.; Qiu, H.; Mu, H.; Xu, X. and Sun, Q. 2018. Preparation of bioactive polysaccharide nanoparticles with enhanced radical scavenging activity and antimicrobial activity. Journal of agricultural and food chemistry, 66(17): 4373-4383.

24. Ravindernath, A. and Reddy, M. S. 2017. Synthesis and evaluation of anti-inflammatory, antioxidant and antimicrobial activities of densely functionalized novel benzo [d] imidazolyl tetrahydropyridine carboxylates. Arabian Journal of Chemistry, 10: S1172-S1179.

25. El Ashry, E.; El Kilany, Y.; Nahas, N.; Barakat, A.; Al-Qurashi, N.; Ghabbour, H. and Fun, H.K., 2016. Synthesis and crystal structures of benzimidazole-2-thione derivatives by alkylation reactions. Molecules, 21(1): 12.

26. Hasanpour, F.; Nekoeinia, M.; Semnani, A. and Shirazinia, R., 2019,Synthesis of semicarbazide catechol derivative as a potential electrode modifier: application in electrocatalysis of catechol amine drugs. Chemical Papers, 73(8): 2081-2089.

27. Mahdi, M. F.; Naser, N. H. and Hammud, N. H. 2017. Synthesis and Preliminary Pharmacological Evaluation of New Naproxen Analogues Having 1, 2, 4-Triazole-3-thiol. International Journal of Pharmacy and Pharmaceutical Sciences, 9(7): 66-71. 